\title{
Emerging viral and bacterial infections of the central nervous system
}

\author{
This article was published in the following Dove Press journal: \\ Neurobehavioral HIV Medicine \\ 27 April 2012 \\ Number of times this article has been viewed
}

\author{
Brian J Balin \\ Christine J Hammond \\ Department of Pathology/ \\ Microbiology/lmmunology and \\ Forensic Medicine, Center for \\ Chronic Disorders of Aging, \\ Philadelphia College of Osteopathic \\ Medicine, Philadelphia, PA, USA
}

Correspondence: Brian J Balin Department of Pathology/Microbiology/ Immunology and Forensic Medicine, Center for Chronic Disorders of Aging, Philadelphia College of Osteopathic Medicine, 4I 70 City Ave, Room 306 Evans Hall, Philadelphia, PA 19131, USA

Tel + I 215 87I 6862

Fax + I 2158716869

Email brianba@pcom.edu

\begin{abstract}
This review focuses on emerging viral and bacterial infections in the human central nervous system (CNS) that are responsible for significant global morbidity and mortality. These infections include those responsible for acute neurological disease such as meningitis and encephalitis as well those associated with chronic neurodegenerative conditions. Recent changes in climate conditions and pollution have been precipitating factors leading to the emergence of many of these pathogenic organisms. In addition, increased urbanization, global travel, life span, and exposure to new vectors have promoted the organisms' spread across the globe. Categorization of many of these organisms includes identification of new species, recognition of new tropism to the CNS, spread into naïve demographic areas, increased human contact with zoonotic repositories including insect vectors, and reemergence of well-known organisms. These mechanisms are highlighted for the different organisms included in this review. Other mechanisms for CNS emergence such as genetic mutation of the organisms and immunosuppression and/or immunosenescence of the host are addressed. Viral and bacterial infections in chronic neurodegenerative diseases traditionally not thought to be infectious are considered. Although this review cannot be all-inclusive, the organisms included represent a sampling of extremely important microbes and their role in CNS pathogenesis in the twenty-first century.
\end{abstract}

Keywords: viruses, bacteria, central nervous system, emergence

Global emergence of central nervous system (CNS) associated infectious disease is currently being recognized. Pathogenic viruses, bacteria, fungi, and protozoa are infecting the human CNS resulting in widespread disease. Global variances including climate changes and pollution have led to changes in these pathogenic organisms. Increased human urbanization, global travel, and life span have led to increased exposure to drug-resistant viral and bacterial strains, as well as to new strains, often through increased zoonotic and vector contact. This review focuses on viral and bacterial infections in the CNS that are causing and/or associated with significant morbidity and mortality in acute neurological disease and chronic neurodegenerative conditions. As research is uncovering associations of viral and bacterial infections with major CNS diseases traditionally not considered caused or exacerbated by infectious entities, we have included these as emerging infections. In this way, this review extends our awareness and understanding of the involvement of infection in the concomitant pathogenesis of CNS disease.

\section{Viruses}

Prior studies and reviews by others have highlighted many viruses (see Table 1) contributing to the new emergence of infection in the human $\mathrm{CNS} .{ }^{1-3}$ Categorization 
of these viruses includes identification of new viral species, recognition of new viral tropism to the CNS, viral spread into naïve demographic areas, increased human contact with zoonotic repositories including insect vectors, and reemergence of well-known viral species. Other mechanisms for CNS emergence include genetic mutation of existing viruses and immunosuppression and/ or immunosenescence of the host. Some of these viruses may be associated with specific disease states such as John Cunningham virus (JC virus) and progressive multifocal leukoencephalopathy, while others, like West Nile virus, appear to play a role in meningitis, encephalitis, or meningoencephalitis.

\section{Identification of new viral species}

Henipaviruses (Hendra and Nipah) in the family Paramyxoviridae were first identified in the mid to late $1990 s^{4,5}$ Hendra infection was first identified in the aseptic meningitis and frank encephalitis deaths of a few Australian individuals who had been in close contact with horses. ${ }^{4}$ Hendra was originally thought to be an equine Morbillivirus but was subsequently reclassified with Nipah virus into the Henipaviruses. Nipah virus is the more frequently encountered virus of the Henipaviruses, and most cases of emergence have resulted from this infection. Nipah was identified originally in pig farmers in Malaysia in 1998 and resulted in acute encephalitis that proved fatal in $>30 \%$ of cases. ${ }^{5,6}$ Common neurological symptoms include fever, headache, segmental myoclonus, reduced tendon reflexes, nuchal rigidity, and seizures. ${ }^{7,8}$ Interestingly, with Nipah

Table I Proposed viruses emerging in central nervous system disease

\begin{tabular}{|c|c|c|}
\hline Virus & $\begin{array}{l}\text { Condition/disease } \\
\text { association }\end{array}$ & Viral family \\
\hline $\begin{array}{l}\text { Henipah virus } \\
\text { (Hendra and Nipah) }\end{array}$ & Encephalitis/meningitis & Paramyxoviridae \\
\hline Enterovirus 7I & $\begin{array}{l}\text { Encephalitis/meningitis/ } \\
\text { flaccid paralysis }\end{array}$ & Picornaviridae \\
\hline West Nile virus & Encephalitis/meningitis & Flaviviridae \\
\hline $\begin{array}{l}\text { Japanese } \\
\text { encephalitis virus }\end{array}$ & Encephalitis & Flaviviridae \\
\hline Chikungunya virus & Encephalitis/meningitis & Togaviridae \\
\hline Influenza virus & Encephalitis/schizophrenia & Orthomyxoviridae \\
\hline $\mathrm{JC}$ virus & $\begin{array}{l}\text { Progressive Multifocal } \\
\text { Leukoencephalopathy (PML) }\end{array}$ & Polyomaviridae \\
\hline $\begin{array}{l}\text { Human } \\
\text { Herpesvirus } 6\end{array}$ & $\begin{array}{l}\text { Encephalitis/epilepsy/ } \\
\text { multiple sclerosis }\end{array}$ & Herpesviridae \\
\hline $\begin{array}{l}\text { Herpes simplex } \\
\text { virus I }\end{array}$ & $\begin{array}{l}\text { Encephalitis/Alzheimer's } \\
\text { disease }\end{array}$ & Herpesviridae \\
\hline
\end{tabular}

infection, 3\% of individuals developed late-onset encephalitis that did not initially have neurological symptoms, and $8 \%$ of acute encephalitic patients had recurrent or relapsing encephalitis on an average of 8 months following acute disease. ${ }^{9}$ Of the fatal cases of Nipah virus infection, analysis of brain tissues at autopsy suggested the virus spreads to the CNS from the bloodstream. Following this spread, there is subsequent multifocal vasculitis, multicentric thrombosis, and direct neuronal infection. ${ }^{10}$ Outbreaks of Nipah virus encephalitis also have appeared in India and Bangladesh with high mortality; however, these are thought to be mitigated by a different source of infection, secretions from the fruit bat. ${ }^{11}$ Newer studies suggest that transmission now can occur from person to person. ${ }^{12}$ Regardless of the mode of transmission, infection with this family of viruses exacts a large toll on the human population, thus keeping these viruses near the top of emerging CNS infectious threats. There is no effective treatment for these viruses other than supportive care.

\section{Viruses emerging in new demographic areas}

Numerous viruses have emerged recently in new demographic areas around the world. Some of the most notable are Enterovirus 71, West Nile virus, Japanese encephalitis virus, and Chikungunya virus. Interestingly, other than for Enterovirus 71, one commonality of these viruses is that they are insect vector borne.

\section{Enterovirus 7I}

Enterovirus 71 (EV71) is a member of the family Picornaviridae and is one of the most important regarding widespread demographic emergence and involvement with CNS disease. This is particularly the case in children in which hand-foot-mouth disease is manifest most often following this infection. ${ }^{2}$ Brainstem encephalitis, acute flaccid paralysis, and aseptic meningitis have been recognized as sequelae in these children, although this may vary with different outbreaks. ${ }^{13,14}$ EV71 was first isolated in California in the late 1960s, but since then there have been numerous outbreaks worldwide with some of the most severe occurring in Southeast Asia and the Pacific Rim nations. ${ }^{15,16}$ During hand-foot-mouth disease epidemics, CNS disease is frequently encountered, and symptoms may include systemic features such as fever, mouth ulcers, cough, vomiting, and irritability. ${ }^{17}$ Treatment for EV71 infections is principally supportive. EV71 and mutated EV71 viruses appear to be one of our greatest threats with emerging Picornaviridae, 
and thus, there is an increasing need for effective and specific vaccines. ${ }^{15}$

\section{West Nile virus}

West Nile virus (WNV), a member of the Flaviviridae family, was first isolated in the West Nile province of Uganda in the 1930s. ${ }^{2}$ The virus has been reported in Central America, the Caribbean, Europe, the Middle East, Africa, India, Asia, and Australia. ${ }^{18,19}$ No cases of WNV encephalitis were recognized in the United States until the late 1990s yet the virus has spread rapidly; today, most states have reported cases of human disease..$^{20,21}$ Culex genus mosquitos are the principal vectors for WNV, and resident bird species are the major host reservoir thought to be responsible for spread of the virus. ${ }^{22}$ The majority of WNV infections are acute and asymptomatic, with approximately $20 \%$ resulting in West Nile Fever and approximately 1\% leading to neuroinvasive disease. ${ }^{23}$ Upon neuroinvasion, encephalitis, meningitis, and acute flaccid paralysis may occur. Individuals 60 years of age or older and afflicted with other conditions, including diabetes and hypertension, are more susceptible to developing encephalitis. ${ }^{24}$ Encephalitis symptoms include mental status change, headache, fever, and Parkinsonian movement disorders. Meningitis symptoms typically consist of headache and fever, photophobia, and, at times, nerve palsies. Individuals exhibiting acute flaccid paralysis also show signs of encephalitis and Parkinsonism change with deficits in nerve conduction; although some of these patients may regain some strength over time, others may not recover. ${ }^{25}$ The clinical course is variable for WNV infections; patients convalescing from meningitis may continue to have persistent headaches and fatigue, while those with encephalitis may manifest persistent neurologic deficits. ${ }^{26}$ There is no specific treatment other than supportive care for infected individuals.

\section{Japanese encephalitis virus}

Similar to WNV, the Japanese encephalitis virus (JEV) is a member of the Flaviviridae, and is transmitted by Culex genus mosquitos. ${ }^{27}$ Natural reservoirs for this virus are pigs, egrets, and herons. JEV was first identified in Japan in the 19th century and has spread over decades into China, Southeast Asia, India, and the Indian subcontinent, New Guinea, and Australia. ${ }^{27}$ The emergence of JEV can be attributed to increased population growth in endemic areas and occupational exposure with rice and pig farming presenting increased risk of vector-borne infection. ${ }^{27} \mathrm{JEV}$ often is asymptomatic, but may cause severe acute encephalitis, which can be fatal. ${ }^{28}$ In this regard, 10,000 deaths or more annually have been attributed to JEV infections and their role in acute viral encephalitis. ${ }^{29,30}$ Symptoms range from nuchal rigidity, severe rigors, and hemiparesis to nausea, headache, and fever. Although there is no specific therapy for JEV, there is a live-attenuated vaccine, and new candidate vaccines are being developed..$^{30}$

\section{Chikungunya virus}

Chikungunya virus (CHIKV), which belongs to the family Togaviridae, is an arbovirus transmitted by the Aedes mosquito (eg, Aedes aegypti). CHIKV was first isolated in Tanzania and subsequently in other areas of sub-Saharan Africa, India, and Southeast Asia. ${ }^{31}$ The virus is considered an encephalitic and arthritic virus. Neurological diseases attributed to CHIKV include encephalitis, meningitis, encephalomyelitis, Guillain-Barré-like syndrome, and acute flaccid paralysis. ${ }^{32-35}$ Experimental evidence from neonatal and adult mice in which the interferon $\alpha / \beta$ receptor was knocked out to prevent interferon signaling suggests that virus inoculated peripherally may enter the choroid plexus of the brain following a viremia. ${ }^{36}$ The association of this virus with CNS disease in humans is thought to arise due to increased geographical distribution by population mobility from endemic areas to naïve areas and possibly by commercial trade of materials containing water-borne mosquito larvae. ${ }^{37}$ In addition, there is evidence from an outbreak of this infection on the island of La Reunion in the Indian Ocean in 2005-2006 that the virus underwent mutation to infect a second Aedes species, Aedes albopictus. ${ }^{31,38-41}$ As Aedes albopictus mosquitos are found in urban areas of Europe and the United States, there is increased risk for this infection to spread in these areas. ${ }^{31,38}$ No specific antiviral treatment or vaccine is currently available.

\section{Genetic mutation of existing viruses and immunosuppression \\ Influenza viruses}

Influenza viruses typically are thought of as respiratory disease-causing agents. However, their ability to undergo genetic mutation, antigenic drift, and affect host development as well as causing neurological symptoms suggests that they will continue to emerge as infections in the CNS. Influenza viruses are members of the family Orthomyxoviridae and typically are associated with symptoms of the flu. ${ }^{42}$ However, there can be neurological involvement as demonstrated during epidemics, and potential involvement in neuropsychiatric disorders following prenatal exposure. There have been 
reports of increasing incidence of influenza-associated encephalitis/encephalopathy, ${ }^{43}$ especially in children infected with influenza A (H1N1). ${ }^{44}$ Other clinical manifestations also may be observed during or following influenza A infections, including Reye's syndrome, myelitis, Guillain-Barré syndrome, and acute necrotizing encephalopathy. ${ }^{43,44}$ Prenatal influenza exposure also has been linked to the development of schizophrenia through analysis of a birth cohort of the Child Health and Development Study. ${ }^{45}$ Brown and colleagues used a case-control study based on this particular cohort to determine that there was a threefold elevation in risk for schizophrenia if there was exposure to influenza in the first half of gestation. ${ }^{46}$ Interestingly, the elevation of risk for schizophrenia was increased sevenfold when exposure occurred within the first trimester, whereas no increase was observed when influenza exposure occurred beyond the second half of gestation. Thus, the vulnerable stage for risk appears to be very early in gestation. ${ }^{46}$ What is not known at this time is the specific mechanism accounting for this risk. Investigations on influenza virus-infected pregnant mice have analyzed specific cellular populations in the brains of the offspring that appear to correlate in later life to decreased exploratory and social behavior, decreased contact with new objects in their environment, and an altered startle response to noise. ${ }^{47,48}$ Of the cellular changes in the offspring, there was a reduction in Cajal-Retzius cells in the cortex and hippocampus that were reelin-positive. ${ }^{47}$ Reelin is involved in regulating neuronal migration and positioning of cells in the developing brain. ${ }^{49}$ In the same mice, there was a decrease in the cortical and hippocampal area but an increase in overall cortical pyramidal cell density. ${ }^{47}$ These studies suggest that influenza virus infection prenatally can have a dramatic result on fetal brain development that may manifest as psychiatric disease at later ages, although causality has yet to be proven conclusively for this involvement. Furthermore, there appears to be an increasing number of reported cases of neurologic sequelae following influenza epidemics. ${ }^{50}$ Often there is no specific treatment for infected individuals, although a number of drugs could be used to help treat and prevent the flu such as oseltamivir (Tamiflu ${ }^{\circledR}$; Hoffman-La Roche, Basel, Switzerland) and zanamivir (Relenza ${ }^{\circledR}$; GlaxoSmithKline, London, UK). ${ }^{51}$

\section{$\mathrm{JC}$ virus}

JC virus is a member of the Polyomaviridae family and causes progressive multifocal leukoencephalopathy (PML), a fatal neurological disease. This disease is observed principally in immunosuppressed or immunocompromised individuals who have low levels of cell-mediated immunity. In this regard, other infections such as those with human immunodeficiency virus (HIV) that result in an immunocompromised state as well as drug therapy for autoimmune diseases such as Crohn's, multiple sclerosis, and rheumatoid arthritis promote an increased incidence of PML. ${ }^{52-55}$ As high percentages of the human population carry antibodies reactive to the $\mathrm{JC}$ virus, the virus is thought to reside latently in the body, systemically and in the CNS. ${ }^{56}$ Upon immunosuppression, reactivation of the virus is thought to occur leading to death of oligodendrocytes and destruction of myelin sheaths in the CNS. Neurological symptoms include weakness, paralysis, vision loss, impaired speech, and cognitive deterioration. ${ }^{56}$ Thus, serious consideration must be made for individuals electing to be treated with many of the newer monoclonal antibody treatments such as natalizumab for Crohn's disease resulting in variable degrees of immunosuppression. ${ }^{54}$

\section{Herpes viruses}

Herpes virus associated with immunocompetent individuals is human herpesvirus 6 (HHV6), a member of the Herpesviridae family. There are two variants (HHV6A and HHV6B). HHV6A is thought to be overall more virulent and neurotropic, although HHV6B is found significantly in CNS disease. ${ }^{57}$ For example, HHV6B is commonly found in childhood and has been associated with exanthem subitum (roseola infantum) and meningoencephalitis. ${ }^{58,59}$ HHV6B also has been associated with infantile febrile illness with documented seizures. ${ }^{60}$ Interestingly, HHV6B has been associated more recently with fatal encephalitis in a number of cases following hematopoietic stem cell transplantation. ${ }^{61}$ Further, studies have found evidence of HHV6B in mesial temporal lobe epilepsy ${ }^{62,63}$ and multiple sclerosis. ${ }^{64}$ However, conclusive disease association with this virus in these diseases awaits further investigation as there is evidence of HHV6 variants in infection in normal human brain tissues. ${ }^{65}$ Commonly, the limbic areas of the brain were affected, including the amygdala, entorhinal cortex, and hippocampus, leading to a designation of posttransplant acute limbic encephalitis. ${ }^{61}$ Ongoing research is investigating the roles of excitatory amino acids and inflammation in the pathological processes associated with HHV6 infection in the CNS. ${ }^{63,66}$ There is no specific treatment for HHV6 infections, but drugs used to treat other herpes infections (eg, ganciclovir) have been tried in severe infections. ${ }^{67}$

Herpes simplex virus 1 (HSV1) is another member of the Herpesviridae family. This virus is ubiquitous and often found latent in peripheral trigeminal ganglion neurons. 
HSV1 may traffic into the CNS proper where the virus may remain latent or reactivate; reactivation can result in serious acute encephalitis of the frontotemporal region of the brain in rare cases. ${ }^{68}$ Regarding neurodegenerative disease, in particular Alzheimer's disease (AD), studies have linked CNS viral infection to AD by analyzing HSV1 DNA in the brain, ${ }^{69-71}$ and anti-HSV1 antibodies in the CSF and sera of patients with AD. ${ }^{71,72}$ Furthermore, HSV1 has been correlated to the apolipoprotein $\mathrm{E} \varepsilon 4$ risk for $\mathrm{AD},{ }^{73}$ and shown to bind to the amyloid precursor protein. ${ }^{74} \mathrm{HSV} 1$ had been demonstrated to code for a protein kinase involved with the phosphorylation of the tau protein. ${ }^{75,76}$ More recently, the virus has been shown to impair the autophagy pathway in cells infected in vitro. ${ }^{77}$ Thus, although great strides have been made in correlating this infection to the neurodegenerative process, ongoing and future studies must continue to focus on the mechanistic underpinnings of infection leading to the emerging nature of HSV1 in AD. With regard to potential therapy in AD, a recent study found that anti-HSV1 antiviral agents reduced $A \beta$ and phosphorylated tau accumulations in HSV1-infected cells in vitro. ${ }^{78}$ Thus, potentially, anti-HSV1 antiviral therapy could be used in HSV1-associated AD.

\section{Bacteria}

Emergence of bacterial infections in the CNS has been demonstrated (see Table 2). This review highlights some of the intracellular and extracellular bacteria contributing to disease in the CNS. Many of these bacteria use specific entry mechanisms into the CNS similar to those used by numerous viruses, including bloodborne entry as well as potential neuroinvasion of peripheral and cranial nerves. ${ }^{79,80}$ With the advent of improved technology such as polymerase chain reaction (PCR) and real-time PCR, microbiome sequencing, and monoclonal antibodies to very specific epitopes, unique bacteria are being identified in the human population. ${ }^{81}$

Table 2 Proposed bacteria emerging in central nervous system disease

\begin{tabular}{|c|c|c|}
\hline Bacteria & $\begin{array}{l}\text { Condition/disease } \\
\text { association }\end{array}$ & $\begin{array}{l}\text { Bacterial } \\
\text { family }\end{array}$ \\
\hline Orientia tsutsugamushi & Meningitis & Rickettsiaceae \\
\hline Ehrlichia chaffeensis & Meningoencephalitis & Anaplasmataceae \\
\hline Chlamydia pneumoniae & $\begin{array}{l}\text { Alzheimer's disease/ } \\
\text { multiple sclerosis }\end{array}$ & Chlamydiaceae \\
\hline Borrelia burgdorferi & $\begin{array}{l}\text { Neuroborreliosis/ } \\
\text { Alzheimer's disease }\end{array}$ & Spirochaetaceae \\
\hline Helicobacter pylori & Parkinson's disease & Helicobacteraceae \\
\hline
\end{tabular}

Note: Although some of these organisms have been associated with acute and/ or chronic CNS disease entities, causality in numerous instances remains to be proven.
Intriguingly, many of these agents are being identified in areas of the body not thought to be initially infected such as the CNS and associated with chronic disease. Chronic disorders, more so than ever before, are being attributed to chronic infectious processes; emerging bacterial infection in the CNS may follow a similar pattern.

\section{Intracellular bacteria}

\section{Orientia tsutsugamushi}

Orientia tsutsugamushi is an obligate intracellular pathogen in the family Rickettsiaceae, and is the causative organism of scrub typhus. ${ }^{82}$ The natural vector and reservoir is the trombiculid mite. ${ }^{83}$ O. tsutsugamushi is a very common infection in Southeast Asia and in the western Pacific Rim countries. Because disease with this organism often presents as a febrile illness, a number of studies have investigated involvement with the CNS..$^{80,84,85}$ The organism is thought to gain access to the CNS following infection of circulating monocytes and invasion of endothelial cells. ${ }^{80}$ Symptoms following entry to the CNS include nuchal rigidity, seizures, delirium, as well as meningismus and meningitis. ${ }^{80,84}$ In the endemic area of scrub typhus, O. tsutsugamushi should be considered a potential causative organism in mononuclear cell-involved meningitis as greater recognition has been demonstrated for the emergence of this Rickettsial organism in CNS disease. ${ }^{85}$ Treatment for infections with O. tsutsugamushi typically includes using the antibiotics doxycycline and/or azithromycin. ${ }^{86}$

\section{Ehrlichia chaffeensis}

Ehrlichia chaffeensis, an obligate intracellular bacterium in the family Anaplasmataceae, causes human monocytic ehrlichiosis (HME). HME rates of infection are estimated to be 100-200 per 100,000 in endemic areas in the US, which include ${ }^{87}$ Mississippi, Oklahoma, Tennessee, Arkansas, and Maryland. ${ }^{88}$ Reports from other states are also being noted suggesting a continual emergence in the US. ${ }^{89}$ Importantly, as up to $66 \%$ of infections with E. chaffeensis are either minimally symptomatic or asymptomatic, the exact incidence of human infection may be higher. ${ }^{90} \mathrm{HME}$ is transmitted by infection with the tick vector, Amblyomma americanum (Lone Star tick), which is prevalent in the southeast and south-central regions of the US. ${ }^{91}$ Neurologic manifestations occur in approximately $20 \%$ of patients infected with HME. Some patients may experience cranial nerve palsy and cognitive deficits, and in children, there may be longer-term sequelae, including foot drop, fine motor impairment, and cognitive change. ${ }^{92}$ Pathogenesis in HME infections appears to result 
from the inability of the cell to undergo phagolysosome fusion, ${ }^{93}$ and to the immune-mediated pathology that results especially with significant expansion of cytotoxic CD8+ $\mathrm{T}$ cells and their production of tumor necrosis factor-alpha and interferon-gamma. ${ }^{94}$ Since 1987 , HME has become a serious and prevalent tick-borne cause of human infections in the US. ${ }^{95}$ With the ever-expanding niche for ticks and animal reservoirs such as white-tailed deer, and their increasing encounters with the resident human population, HME will continue to emerge as a major cause of vector-borne meningoencephalitis. Treatment for HME typically involves a course of antibiotic therapy with doxycycline. ${ }^{96}$

\section{Chlamydia pneumoniae}

Chlamydia pneumoniae (Cpn), an obligate intracellular bacterium in the family Chlamydiaceae, typically infects the human respiratory tract often resulting in a chronic cough, little sputum production, and a low-grade fever. ${ }^{97}$ The organism has been shown to enter the systemic circulation following infection of monocytes surveilling lung tissues. ${ }^{98}$ The ability to spread systemically may be one reason this bacterium has been identified in nonrespiratory conditions, including $\mathrm{AD}$ and multiple sclerosis (MS). Associations of Cpn with $\mathrm{AD}^{99}$ and $\mathrm{MS}^{100}$ were first reported in 1998. Over the last several years, other reports have strengthened these associations, ${ }^{101,102}$ but more evidence is required to demonstrate proof of causality. In this regard, studies have addressed and continue to address Cpn infection in vivo in diseased populations and in animal models, and in vitro in infected tissue cultures. What is becoming clearer is that Cpn can enter and remain in the CNS as a chronic/ persistent infection, ${ }^{103,104}$ and may be a major stimulus for neuroinflammation. ${ }^{105}$ Furthermore, infection of the brain may involve not only monocyte delivery but also infection of the olfactory cranial nerve following exposure in the nose. Evidence for this pathway follows from analysis of olfactory tissues from patients with $\mathrm{AD},{ }^{99}$ as well as animal models. ${ }^{103}$ Molecular analyses following Cpn infection in cell culture are addressing specific pathways known to be disrupted or modified in AD. For example, modification of apoptosis ${ }^{106}$ and autophagy pathways as well as inflammatory pathways following infection are being studied to better understand the molecular pathogenesis of infection-mediated disease. In effect, continued correlation of CNS infection with Cpn and $\mathrm{AD}$ and MS may reflect the relatively newly recognized emergence of chronic infection with major neurological diseases. Treatment for community-acquired pneumonias, including those caused by Cpn, typically involves antibiotics such as doxycycline, azithromycin, and/or fluoroquinolones. ${ }^{107}$ One clinical trial with some positive results has been performed using the anti-Cpn antibiotics doxycycline and rifampin in treating patients with $\mathrm{AD} .{ }^{108}$

\section{Extracellular bacteria}

\section{Borrelia burgdorferi}

Borrelia burgdorferi organisms are spirochetes in the family of Spirochaetaceae that cause borreliosis or Lyme disease, a zoonotic, vector-borne disease transmitted primarily by ticks such as Ixodes scapularis in North America. Typically, a localized infection occurs following the tick bite, and evasion of the immune system ensues once in the host. ${ }^{109}$ $B$. burgdorferi infects monocytes that are thought to disseminate the organism into the CNS through the blood-brain barrier. ${ }^{109}$ Once the organism is in the brain, a chronic infection may ensue in which neuroborreliosis and/or Alzheimer's disease may become manifest. ${ }^{110}$ Symptoms of nervous system involvement may include meningoradiculitis, cranial nerve abnormalities, and altered mental status. ${ }^{109}$ Evidence for involvement in $\mathrm{AD}$ comes from analysis of postmortem AD brain tissues in which Borrelia was identified. ${ }^{111}$ Further studies in vitro have supported these findings by demonstrating that infection of neurons, astrocytes, and microglial cells led to the production and aggregation of amyloid as well as tangle-like structures within nerve cells. ${ }^{112}$ In this regard, bacterial products from the organism such as lipopolysaccharide have been shown to initiate a strong response by neuronal and glial cells implicating Borrelia with AD. ${ }^{112}$ At this time, causality has not been determined regarding this infection and AD pathogenesis; however, the infection induction of beta amyloid processing and tau hyperphosphorylation comparable to what is observed in $\mathrm{AD}$ makes B. burgdorferi a candidate infection as a stimulus for CNS damage. ${ }^{112}$ Neuroborreliosis is typically treated with intravenous antibiotics that cross the blood-brain barrier such as ceftriaxone and doxycycline. ${ }^{113}$

\section{Helicobacter pylori}

Helicobacter pylori are members of the Helicobacteraceae family. Infection with this organism in the stomach is considered the major cause of peptic and gastric ulcers. ${ }^{114} \mathrm{H}$. pylori infection has been postulated to play a role in idiopathic Parkinson's (IP) disease. ${ }^{115}$ This follows from analysis of common immunological manifestations, epidemiological similarities of familial aggregation and linkage with a common source of drinking water, and the demonstration that the infection can be passed between siblings in childhood 
and between spouses. ${ }^{115}$ Probands with IP and siblings share a threefold increase in odds of seropositivity for antibodies against $H$. pylori urease. ${ }^{116}$ Furthermore, a discriminant index for the presence/absence of diagnosed Parkinsonism has been derived from Western blot serum H. pylori antibody profiles in subjects with and without IP that contained known pathogenicity markers. ${ }^{117}$ The persistence of antibody against cytotoxin-associated antigen (CagA) increased the predicted probability of Parkinsonism by 80 years of age fivefold. ${ }^{117}$ More recently, a population-based study of patients with Parkinson's in Denmark suggested chronic H. pylori infection and/or gastritis either contributed to Parkinson's disease (PD) or that these are PD-related pathologies that precede motor dysfunction. ${ }^{118}$ Mechanistically, chronic inflammation and autoimmune modulation have been proposed as contributors to IP with $H$. pylori infection. ${ }^{115}$ Some evidence for immune modulation has been demonstrated in vitro as H. pylori has been shown to suppress T-cell proliferation, ${ }^{119}$ and in infected individuals, $H$. pylori-specific T-regs have been shown to suppress T-cell responses. ${ }^{120}$ Extraintestinal influence in IP may be more prominent with CagA-positive strains of $H$. pylori regarding autoimmune mechanisms. ${ }^{121}$ The exact relationship between $H$. pylori infection and IP has yet to be determined. What is becoming clearer is that relationships may exist between the gut and brain such that infectious components arising in the gastrointestinal tract affect brain function. Treatment for $H$. pylori gastric infection typically includes the combination of two antibiotics such as clarithromycin and metronidazole and a proton pump inhibitor such as omeprazole, sometimes together with a bismuth compound. ${ }^{122}$

\section{Conclusion}

Emerging viruses and bacteria in the CNS are significant contributors to increased morbidity and mortality in human populations worldwide. Recognition of this emergence is vital in developing adequate preventive regimens, diagnostic procedures, and treatment measures. Clinicians and infectious disease researchers must be aware of acute and chronic processes of infectious origin that may be insulting the nervous system. Neurological diseases not typically thought to be infectious must be examined fully for microbial involvement and analyzed for direct and indirect associations. We are challenged to develop methodology that will clearly detect and identify infectious agents in the CNS. Finally, understanding the relationships between systemic infection and neurologic disease is vital, and may provide clues leading to better predictability, treatment, and prevention of CNS diseases.

\section{Acknowledgments}

The authors are supported in part by the Center for Chronic Disorders of Aging at Philadelphia College of Osteopathic Medicine and the Adolph and Rose Levis Foundation Laboratory for Alzheimer's disease research.

\section{Disclosure}

The authors report no conflict of interest in this work.

\section{References}

1. Olival KJ, Daszak P. The ecology of emerging neurotropic viruses. J Neurovirol. 2005;11(5):441-446.

2. Tyler KL. Emerging viral infections of the central nervous system: part 1. Arch Neurol. 2009;66(8):939-948.

3. Tyler KL. Emerging viral infections of the central nervous system: part 2. Arch Neurol. 2009;66(9):1065-1074

4. O'Sullivan JD, Allworth AM, Paterson DL, et al. Fatal encephalitis due to novel paramyxovirus transmitted from horses. Lancet. 1997; 349(9045):93-95.

5. Chua KB, Goh KJ, Wong KT, et al. Fatal encephalitis due to Nipah virus among pig-farmers in Malaysia. Lancet. 1999;354(9186):1257-1259.

6. Chua KB, Bellini WJ, Rota PA, et al. Nipah virus: a recently emergen deadly paramyxovirus. Science. 2000;288(5470):1432-1435.

7. Goh KJ, Tan CT, Chew NK, et al. Clinical features of Nipah virus encephalitis among pig farmers in Malaysia. $N$ Engl J Med. 2000; 342(17):1229-1235.

8. Lee KE, Umapathi T, Tan CB, et al. The neurological manifestations of Nipah virus encephalitis, a novel paramyxovirus. Ann Neurol. 1999; 46(3):428-432.

9. Tan CT, Goh KJ, Wong KT, et al. Relapsed and late-onset Nipah encephalitis. Ann Neurol. 2002;51(6):703-708.

10. Wong KT, Shieh W, Kumar S, et al. Nipah virus infection: pathology and pathogenesis of an emerging paramyxoviral zoonosis. Am J Pathol. 2002;161(6):2153-2167.

11. Chadha MS, Comer JA, Lowe L, et al. Nipah virus-associated encephalitis outbreak, Siliguri, India. Emerg Infect Dis. 2006;12(2):235-240.

12. Gurley ES, Montgomery JM, Hossain MJ, et al. Person-to-person transmission of Nipah virus in a Bangladeshi community. Emerg Infect Dis. 2007;13(7):1031-1037.

13. Ishimaru Y, Nakano S, Yamaoka K, Takami S. Outbreaks of hand, foot, and mouth disease by enterovirus 71. High incidence of complication disorders of central nervous system. Arch Dis Child. 1980;55(8): 583-588.

14. Weng KF, Chen LL, Huang PN, Shih SR. Neural pathogenesis of enterovirus 71 infection. Microbes Infect. 2010;12(7):505-510.

15. Huang SW, Kiang D, Smith DJ, Wang JR. Evolution of re-emergent virus and its impact on enterovirus 71 epidemics. Exp Biol Med (Maywood). 2011;236(8):899-908.

16. Chan KP, Goh KT, Chong CY, Teo ES, Lau G, Ling AE. Epidemic hand, foot and mouth disease caused by human enterovirus 71, Singapore. Emerg Infect Dis. 2003;9(1):78-85.

17. Ooi MH, Wong SC, Podin Y, et al. Human enterovirus 71 disease in Sarawak, Malaysia: a prospective clinical, virological, and molecular epidemiological study. Clin Infect Dis. 2007;44(5):646-656.

18. Dauphin G, Zientara S, Zeller H, Murgue B. West Nile: worldwide current situation in animals and humans. Comp Immunol Microbiol Infect Dis. 2004;27(5):343-355.

19. Zeller HG, Schuffenecker I. West Nile virus: an overview of its spread in Europe and the Mediterranean basin in contrast to its spread in the Americas. Eur J Clin Microbiol Infect Dis. 2004;23(3):147-156.

20. Hayes EB, Komar N, Nasci RS, Montgomery SP, O’Leary DR, Campbell GL. Epidemiology and transmission dynamics of West Nile virus disease. Emerg Infect Dis. 2005;11(8):1167-1173. 
21. Nash D, Mostashari F, Fine A, et al. The outbreak of West Nile virus infection in the New York City area in 1999. N Engl J Med. 2001; 344(24):1807-1814.

22. Rappole JH, Compton BW, Leimgruber P, Robertson J, King DI, Renner SC. Modeling movement of West Nile virus in the Western hemisphere. Vector Borne Zoonotic Dis. 2006;6(2):128-139.

23. Hayes EB, Sejvar JJ, Zaki SR, Lanciotti RS, Bode AV, Campbell GL. Virology, pathology, and clinical manifestations of West Nile virus disease. Emerg Infect Dis. 2005;11(8):1174-1179.

24. Murray KO, Baraniuk S, Resnick M, et al. Risk factors for encephalitis and death from West Nile virus infection. Epidemiol Infect. 2006; 134(6):1325-1332.

25. Sejvar JJ, Bode AV, Marfin AA, et al. West Nile virus-associated flaccid paralysis. Emerg Infect Dis. 2005;11(7):1021-1027.

26. Sejvar JJ, Haddad MB, Tierney BC, et al. Neurologic manifestations and outcome of West Nile virus infection. JAMA. 2003;290(4): 511-515.

27. Erlanger TE, Weiss S, Keiser J, Utzinger J, Wiedenmayer K. Past, present, and future of Japanese encephalitis. Emerg Infect Dis. 2009; 15(1):1-7.

28. Ghosh D, Basu A. Japanese encephalitis-a pathological and clinical perspective. PLoS Negl Trop Dis. 2009;3(9):e437.

29. Campbell GL, Hills SL, Fischer M, et al. Estimated global incidence of Japanese encephalitis: a systematic review. Bull World Health Organ. 2011;89(10):766-774, 774A-774E.

30. Solomon T. Control of Japanese encephalitis - within our grasp? N Engl J Med. 2006;355(9):869-871.

31. Pialoux G, Gaüzère B-, Jauréguiberry S, Strobel M. Chikungunya, an epidemic arbovirosis. Lancet Infect Dis. 2007;7(5):319-327.

32. Robin S, Ramful D, Le Seach' F, Jaffar-Bandjee MC, Rigou G, Alessandri JL. Neurologic manifestations of pediatric chikungunya infection. J Child Neurol. 2008;23(9):1028-1035.

33. Ganesan K, Diwan A, Shankar SK, Desai SB, Sainani GS, Katrak SM. Chikungunya encephalomyeloradiculitis: report of 2 cases with neuroimaging and 1 case with autopsy findings. Am J Neuroradiol. 2008;29(9):1636-1637.

34. Singh SS, Manimunda SP, Sugunan AP, Sahina P, Vijayachari P. Four cases of acute flaccid paralysis associated with chikungunya virus infection. Epidemiol Infect. 2008;136(9):1277-1280.

35. Das T, Jaffar-Bandjee MC, Hoarau JJ, et al. Chikungunya fever: CNS infection and pathologies of a re-emerging arbovirus. Prog Neurobiol. 2010;91(2):121-129.

36. Couderc T, Chretien F, Schilte C, et al. A mouse model for Chikungunya: young age and inefficient type-I interferon signaling are risk factors for severe disease. PLoS Pathog. 2008;4(2):e29.

37. Nero C. Chikungunya, the traveling virus. Clin Microbiol Newsl. 2008; 30(13):97-100.

38. Charrel RN, de Lamballerie X, Raoult D. Chikungunya outbreaks - the globalization of vectorborne diseases. New Engl J Med. 2007;356(8):769-771.

39. Schuffenecker I, Iteman I, Michault A, et al. Genome microevolution of chikungunya viruses causing the Indian Ocean outbreak. PLoS Med. 2006;3(7):1058-1070.

40. Tsetsarkin KA, Vanlandingham DL, McGee CE, Higgs S. A single mutation in chikungunya virus affects vector specificity and epidemic potential. PLoS Pathog. 2007;3(12):e201.

41. Tsetsarkin KA, Weaver SC. Sequential adaptive mutations enhance efficient vector switching by chikungunya virus and its epidemic emergence. PLoS Pathog. 2011;7(12):e1002412.

42. Eccles R. Understanding the symptoms of the common cold and influenza. Lancet Infect Dis. 2005;5(11):718-725.

43. Writing Committee of the Second World Health Organization Consultation on Clinical Aspects of Human Infection with Avian Influenza A (H5N1) Virus, Abdel-Ghafar AN, Chotpitayasunondh T, et al. Update on avian influenza A (H5N1) virus infection in humans. N Engl J Med. 2008;358(3):261-273.
44. Farooq O, Faden HS, Cohen ME, et al. Neurologic complications of 2009 influenza-A H1 N1 infection in children. J Child Neurol. 2011. Epub October 12, 2011.

45. Susser ES, Schaefer CA, Brown AS, Begg MD, Wyatt RJ. The design of the prenatal determinants of schizophrenia study. Schizophr Bull. 2000;26(2):257-273.

46. Brown AS, Begg MD, Gravenstein S, et al. Serologic evidence of prenatal influenza in the etiology of schizophrenia. Arch Gen Psychiatry. 2004;61(8):774-780.

47. Fatemi SH, Emamian ES, Kist D, et al. Defective corticogenesis and reduction in Reelin immunoreactivity in cortex and hippocampus of prenatally infected neonatal mice. Mol Psychiatry. 1999;4(2):145-154.

48. Shi L, Fatemi SH, Sidwell RW, Patterson PH. Maternal influenza infection causes marked behavioral and pharmacological changes in the offspring. J Neurosci. 2003;23(1):297-302.

49. Niu S, Renfro A, Quattrocchi CC, Sheldon M, D'Arcangelo G. Reelin promotes hippocampal dendrite development through the VLDLR/ ApoER2-Dab1 pathway. Neuron. 2004;41(1):71-84.

50. Davis LE. Neurologic and muscular complications of the 2009 influenzaA (H1N1) pandemic. Curr Neurol Neurosci Rep. 2010;10(6):476-483.

51. Hsu J, Santesso N, Mustafa R, et al. Antivirals for treatment of influenza: a systematic review and meta-analysis of observational studies. Ann Intern Med. 2012. Epub February 27, 2012.

52. Engsig FN, Hansen A-E, Omland LH, et al. Incidence, clinical presentation, and outcome of progressive multifocal leukoencephalopathy in HIV-infected patients during the highly active antiretroviral therapy era: a nationwide cohort study. J Infect Dis. 2009;199(1):77-83.

53. Calabrese LH, Molloy ES, Huang D, Ransohoff RM. Progressive multifocal leukoencephalopathy in rheumatic diseases: evolving clinical and pathologic patterns of disease. Arthritis Rheum. 2007;56(7):2116-2128.

54. Van Assche G, Van Ranst M, Sciot R, et al. Progressive multifocal leukoencephalopathy after natalizumab therapy for Crohn's disease. N Engl J Med. 2005;353(4):362-368.

55. Stüve O, Marra CM, Jerome KR, et al. Immune surveillance in multiple sclerosis patients treated with natalizumab. Ann Neurol. 2006;59(5): 743-747.

56. Berger JR. Progressive multifocal leukoencephalopathy. Curr Neurol Neurosci Rep. 2007;7(6):461-469.

57. Dewhurst S, McIntyre K, Schnabel K, Hall CB. Human herpesvirus 6 (HHV-6) variant B accounts for the majority of symptomatic primary HHV-6 infections in a population of US infants. J Clin Microbiol. 1993;31(2):416-418.

58. Yamanishi K, Okuno T, Shiraki K, et al. Identification of human herpesvirus-6 as a causal agent for exanthem subitum. Lancet. 1988; 1(8594):1065-1067.

59. Yoshikawa T, Nakashima T, Suga S, et al. Human herpesvirus-6 DNA in cerebrospinal fluid of a child with exanthem subitum and meningoencephalitis. Pediatrics. 1992;89(5 Pt 1):888-890.

60. Hall CB, Long CE, Schnabel KC, et al. Human herpesvirus-6 infection in children. A prospective study of complications and reactivation. N Engl J Med. 1994;331(7):432-438.

61. Seeley WW, Marty FM, Holmes TM, et al. Post-transplant acute limbic encephalitis: clinical features and relationship to HHV6. Neurology. 2007;69(2):156-165.

62. Donati D, Akhyani N, Fogdell-Hahn A, et al. Detection of human herpesvirus-6 in mesial temporal lobe epilepsy surgical brain resections. Neurology. 2003;61(10):1405-1411.

63. Fotheringham J, Donati D, Akhyani N, et al. Association of human herpesvirus-6B with mesial temporal lobe epilepsy. PLoS Med. 2007; 4(5):e180

64. Goodman AD, Mock DJ, Powers JM, Baker JV, Blumberg BM. Human herpesvirus 6 genome and antigen in acute multiple sclerosis lesions. J Infect Dis. 2003;187(9):1365-1376.

65. Chan PKS, Ng HK, Hui M, Ip M, Cheung JLK, Cheng AF. Presence of human herpesviruses 6,7, and 8 DNA sequences in normal brain tissue. J Med Virol. 1999;59(4):491-495. 
66. Vezzani A, Granata T. Brain inflammation in epilepsy: experimental and clinical evidence. Epilepsia. 2005;46(11):1724-1743.

67. Olli-Lahdesmaki T, Haataja L, Parkkola R, Waris M, Bleyzac N, Ruuskanen O. High-dose ganciclovir in HHV-6 encephalitis of an immunocompetent child. Pediatr Neurol. 2010;43(1):53-56.

68. Whitley RJ. Herpes simplex encephalitis: adolescents and adults. Antiviral Res. 2006;71(2-3):141-148.

69. Jamieson GA, Maitland NJ, Craske J, Wilcock GK, Itzhaki RF. Detection of herpes simplex virus type 1 DNA sequences in normal and Alzheimer's disease brain using polymerase chain reaction. Biochem Soc Trans. 1991;19(2):122S.

70. Wozniak MA, Mee AP, Itzhaki RF. Herpes simplex virus type 1 DNA is located within Alzheimer's disease amyloid plaques. J Pathol. 2009; 217(1):131-138

71. Wozniak MA, Shipley SJ, Combrinck M, Wilcock GK, Itzhaki RF. Productive herpes simplex virus in brain of elderly normal subjects and Alzheimer's disease patients. J Med Virol. 2005;75(2):300-306.

72. Letenneur L, Pérès K, Fleury H, et al. Seropositivity to herpes simplex virus antibodies and risk of Alzheimer's disease: a population-based cohort study. PLoS One. 2008;3(11):e3637.

73. Itzhaki RF, Lin WR, Shang D, Wilcock GK, Faragher B, Jamieson GA. Herpes simplex virus type 1 in brain and risk of Alzheimer's disease [see comments]. Lancet. 1997;349(9047):241-244.

74. Cheng SB, Ferland P, Webster P, Bearer EL. Herpes simplex virus dances with amyloid precursor protein while exiting the cell. PLoS One. 2011;6(3):e17966.

75. Wozniak MA, Frost AL, Itzhaki RF. Alzheimer's disease-specific tau phosphorylation is induced by herpes simplex virus type 1. JAlzheimers Dis. 2009;16(2):341-350.

76. Benetti L, Roizman B. Herpes simplex virus protein kinase Us 3 activates and functionally overlaps protein kinase A to block apoptosis. Proc Natl Acad Sci U S A. 2004;101(25):9411-9416.

77. Santana S, Recuero M, Bullido MJ, Valdivieso F, Aldudo J. Herpes simplex virus type I induces the accumulation of intracellular betaamyloid in autophagic compartments and the inhibition of the nonamyloidogenic pathway in human neuroblastoma cells. Neurobiol Aging. 2012;33(2):430.e19-e33. Epub January 26, 2011.

78. Wozniak MA, Frost AL, Preston CM, Itzhaki RF. Antivirals reduce the formation of key alzheimer's disease molecules in cell cultures acutely infected with herpes simplex virus type 1. PLoS One. 2011; 6(10):e25152.

79. McGavern DB, Kang SS. Illuminating viral infections in the nervous system. Nat Rev Immunol. 2011;11(5):318-329.

80. Drevets DA, Leenen PJ, Greenfield RA. Invasion of the central nervous system by intracellular bacteria. Clin Microbiol Rev. 2004;17(2): 323-347.

81. Henry CS, Overbeek R, Xia F, et al. Connecting genotype to phenotype in the era of high-throughput sequencing. Biochim Biophys Acta. 2011; 1810(10):967-977.

82. Watt G, Parola P. Scrub typhus and tropical rickettsioses. Curr Opin Infect Dis. 2003;16(5):429-436.

83. Kelly DJ, Fuerst PA, Ching WM, Richards AL. Scrub typhus: The geographic distribution of phenotypic and genotypic variants of Orientia tsutsugamushi. Clin Infect Dis. 2009;48(Suppl 3):S203-S230.

84. Kim DE, Lee SH, Park KI, Chang KH, Roh JK. Scrub typhus encephalomyelitis with prominent focal neurologic signs. Arch Neurol. 2000; 57(12):1770-1772.

85. Mahajan SK, Rolain J, Kanga A, Raoult D. Scrub typhus involving central nervous system, India, 2004-2006. Emerg Infect Dis. 2010;16(10): 1641-1643.

86. Rajapakse S, Rodrigo C, Fernando SD. Drug treatment of scrub typhus. Trop Doct. 2011;41(1):1-4.

87. Olano JP, Hogrefe W, Seaton B, Walker DH. Clinical manifestations, epidemiology, and laboratory diagnosis of human monocytotropic ehrlichiosis in a commercial laboratory setting. Clin Diagn Lab Immunol. 2003;10(5):891-896.
88. Demma LJ, Holman RC, McQuiston JH, Krebs JW, Swerdlow DL. Human monocytic ehrlichiosis and human granulocytic anaplasmosis in the United States, 2001-2002. Ann NY Acad Sci. 2006;1078: $118-119$

89. Olano JP, Masters E, Hogrefe W, Walker DH. Human monocytotropic ehrlichiosis, Missouri. Emerg Infect Dis. 2003;9(12):1579-1586.

90. Marshall GS, Jacobs RF, Schutze GE, et al. Ehrlichia chaffeensis seroprevalence among children in the southeast and south-central regions of the United States. Arch Pediatr Adolesc Med. 2002;156(2):166-170.

91. Anderson BE, Sims KG, Olson JG, et al. Amblyomma americanum: a potential vector of human ehrlichiosis. Am J Trop Med Hyg. 1993; 49(2):239-244

92. Ratnasamy N, Everett ED, Roland WE, McDonald G, Caldwell CW. Central nervous system manifestations of human ehrlichiosis. Clin Infect Dis. 1996;23(2):314-319.

93. Rikihisa Y. Ehrlichia subversion of host innate responses. Curr Opin Microbiol. 2006;9(1):95-101.

94. Dierberg KL, Dumler JS. Lymph node hemophagocytosis in rickettsial diseases: a pathogenetic role for CD8 T lymphocytes in human monocytic ehrlichiosis (HME)? BMC Infect Dis. 2006;6:121.

95. Ismail N, Bloch KC, McBride JW. Human ehrlichiosis and anaplasmosis. Clin Lab Med. 2010;30(1):261-292.

96. Thomas RJ, Dumler JS, Carlyon JA. Current management of human granulocytic anaplasmosis, human monocytic ehrlichiosis and Ehrlichia ewingii ehrlichiosis. Expert Rev Anti Infect Ther. 2009;7(6): 709-722.

97. Grayston JT, Campbell LA, Kuo CC, et al. A new respiratory tract pathogen: Chlamydia pneumoniae strain TWAR. J Infect Dis. 1990;161: 618-625.

98. Moazed TC, Kuo CC, Grayston JT, Campbell LA. Evidence of systemic dissemination of Chlamydia pneumoniae via macrophages in the mouse. J Infect Dis. 1998;177(5):1322-1325.

99. Balin BJ, Gerard HC, Arking EJ, et al. Identification and localization of Chlamydia pneumoniae in the Alzheimer's brain. Med Microbiol Immunol (Berl). 1998;187(1):23-42.

100. Sriram S, Mitchell W, Stratton C. Multiple sclerosis associated with Chlamydia pneumoniae infection of the CNS. Neurology. 1998;50(298145402):571-572.

101. Balin BJ, Little CS, Hammond CJ, et al. Chlamydophila pneumoniae and the etiology of late-onset Alzheimer's disease. J Alzheimers Dis. 2008;13(4):371-380.

102. Contini C, Seraceni S, Cultrera R, Castellazzi M, Granieri E, Fainardi E. Chlamydophila pneumoniae infection and its role in neurological disorders. Interdiscip Perspect Infect Dis. 2010;2010:273573. Epub February 21, 2010.

103. Little CS, Hammond CJ, MacIntyre A, Balin BJ, Appelt DM. Chlamydia pneumoniae induces Alzheimer-like amyloid plaques in brains of BALB/c mice. Neurobiol Aging. 2004;25(4):419-429.

104. Little CS, Bowe A, Lin R, et al. Age alterations in extent and severity of experimental intranasal infection with Chlamydophila pneumoniae in BALB/c mice. Infect Immun. 2005;73(3):1723-1734.

105. Boelen E, Steinbusch HW, Bruggeman CA, Stassen FR. The inflammatory aspects of Chlamydia pneumoniae-induced brain infection. Drugs Today (Barc). 2009;45(Suppl B):159-164.

106. Appelt DM, Roupas MR, Way DS, et al. Inhibition of apoptosis in neuronal cells infected with Chlamydophila (Chlamydia) pneumoniae. BMC Neurosci. 2008;9:13.

107. Thiem U, Heppner HJ, Pientka L. Elderly patients with communityacquired pneumonia: optimal treatment strategies. Drugs Aging. 2011 28(7):519-537.

108. Loeb MB, Molloy DW, Smieja M, et al. A randomized, controlled trial of doxycycline and rifampin for patients with Alzheimer's disease. $J$ Am Geriatr Soc. 2004;52(3):381-387.

109. Rupprecht TA, Koedel U, Fingerle V, Pfister HW. The pathogenesis of lyme neuroborreliosis: from infection to inflammation. Mol Med. 2008;14(3-4):205-212. 
110. MacDonald AB, Miranda JM. Concurrent neocortical borreliosis and Alzheimer's disease. Hum Pathol. 1987;18(7):759-761.

111. Miklossy J. Alzheimer's disease - a spirochetosis? Neuroreport. 1993; 4(7):841-848.

112. Miklossy J, Kis A, Radenovic A, et al. Beta-amyloid deposition and Alzheimer's type changes induced by Borrelia spirochetes. Neurobiol Aging. 2006;27(2):228-236.

113. O'Connell S. Lyme borreliosis: current issues in diagnosis and management. Curr Opin Infect Dis. 2010;23(3):231-235.

114. Cover TL, Blaser MJ. Helicobacter pylori in health and disease. Gastroenterology. 2009;136(6):1863-1873.

115. Dobbs SM, Dobbs RJ, Weller C, Charlett A. Link between Helicobacter pylori infection and idiopathic parkinsonism. Med Hypotheses. 2000;55(2):93-98.

116. Charlett A, Dobbs RJ, Dobbs SM, Weller C, Brady P, Peterson DW. Parkinsonism: siblings share Helicobacter pylori seropositivity and facets of syndrome. Acta Neurol Scand. 1999;99(1):26-35.

117. Weller C, Charlett A, Oxlade NL, et al. Role of chronic infection and inflammation in the gastrointestinal tract in the etiology and pathogenesis of idiopathic parkinsonism. Part 3: predicted probability and gradients of severity of idiopathic parkinsonism based on $\mathrm{H}$. pylori antibody profile. Helicobacter. 2005;10(4):288-297.
118. Nielsen HH, Qiu J, Friis S, Wermuth L, Ritz B. Treatment for Helicobacter pylori infection and risk of Parkinson's disease in Denmark. Eur J Neurol. 2012. Epub January 17, 2012.

119. Gerhard M, Rad R, Prinz C, Naumann M. Pathogenesis of Helicobacter pylori infection. Helicobacter. 2002;7(Suppl 1):17-23.

120. Lundgren A, Suri-Payer E, Enarsson K, Svennerholm AM, Lundin BS. Helicobacter pylori-specific CD4+ CD25high regulatory T cells suppress memory T-cell responses to $\mathrm{H}$. pylori in infected individuals. Infect Immun. 2003;71(4):1755-1762.

121. Gasbarrini A, Carloni E, Gasbarrini G, Chisholm SA. Helicobacter pylori and extragastric diseases - other Helicobacters. Helicobacter. 2004;9(Suppl 1):57-66.

122. Chuah SK, Tsay FW, Hsu PI, Wu DC. A new look at anti-Helicobacter pylori therapy. World J Gastroenterol. 2011;17(35):3971-3975.
Neurobehavioral HIV Medicine

\section{Publish your work in this journal}

Neurobehavioral HIV Medicine is an international, peer-reviewed, open access journal focusing on advances in research in HIV/ AIDS, with specific reference to the neurological, psychiatric and behavioral consequences of the disease, concomitant infections and specific antiretroviral therapy. The manuscript

\section{Dovepress}

management system is completely online and includes a very quick and fair peer-review system, which is all easy to use. Visit http://www.dovepress.com/testimonials.php to read real quotes from published authors. 